\title{
Redescription of the Neotropical species Trichodischia soror Bigot, 1885 (Diptera: Tachinidae), with a new generic synonymy
}

\author{
Deivys M. Alvarez-Garcia ${ }^{1,2,3}$ \& Marcelo Domingos de Santis ${ }^{2,4}$
}

\author{
1 Universidad de Sucre (UNISUCRE), Grupo de Investigación en Zoología y Ecología. Sincelejo, Sucre, Colombia. \\ ${ }^{2}$ Universidade de São Paulo (USP), Instituto de Biociências (IB-USP), Departamento de Zoologia, \\ Laboratório de Sistemática e Biogeografia de Insecta. São Paulo, SP, Brasil. \\ ${ }^{3}$ ORCID: http://orcid.org/0000-0002-7545-5638. E-mail: deivysalvarez@gmail.com (corresponding author) \\ ${ }^{4}$ ORCID: http://orcid.org/0000-0003-4949-6433. E-mail:mrclsantis@gmail.com
}

\begin{abstract}
Trichodischia Bigot, 1885 is a Neotropical genus with a confusing taxonomic history. This was initially composed of two species: T. caerulea Bigot, 1885 and T. soror Bigot, 1885. Later, the genus Trichoraea Cortés, 1974 was erected for T. caerulea. When reviewing the taxonomic history of both species, we discovered that both genera have been considered synonymous based on erroneous information and without a formal synonymy being proposed. Herein, we redescribed $T$. soror, provide images of adults and describe the male terminalia for the first time. In addition, by examining the type material, we propose Trichoraea as a junior synonym of Trichodischia, syn. nov., confirm T. caerulea comb. rest. and T. soror as valid species and provide some comments about the taxonomy and host record of the genus.
\end{abstract}

Keywords. Dexiinae; Macquartiini; Taxonomy; Trichoraea; Voriini.

\section{INTRODUCTION}

Trichodischia Bigot, 1885 is a Neotropical genus belonging to the tribe Voriini and subfamily Dexiiinae (Tachinidae) (O'Hara et al., 2020). This genus was originally composed of two species: T. caerulea Bigot, 1885 and T. soror Bigot, 1885; both species with a complex and confusing taxonomic history. Brauer (1898) was the first revisor redescribing both species and providing some taxonomic notes. Cortés (1944) synonymized both species, letting just T. caerulea as valid. Later, Cortés (1969) revalidated T. soror and provided a diagnostic key for both species; with the most conspicuous difference being the dark metallic blue color of scutum and abdomen in T. caerulea, whereas T. soror presents the scutum and abdomen brownish black. Lastly, Cortés (1974) changed his mind and considered T. caerulea as belonging to a distinct genus from Trichodischia, erecting the genus Trichoraea Cortés, 1974 for this species.

In the same way, the validity of the genus Trichoraea remained unclear. The matter begins when Guimarães (1977) wrongly catalogued Trichodischia caerulea as a parasitoid of Spodoptera frugiperda, relying on the work of Blanchard (1963). There is no way of knowing if this error was caused by some distraction when cataloging the name of the species or by ignorance of the work of Cortés (1974), who, in addition to creating the genus Trichoraea, also concluded that the specimen cited by Blanchard (1963) was actually T. soror. This error led more authors (e.g., Henry, 1987; O'Hara et al., 2020) to wrongly cited the species as Trichodischia caerulea instead of Trichoraea caerulea, and the genus Trichoraea was assumed as synonym of Trichodischia without any formal proposition of synonymy (e.g., O'Hara \& Henderson, 2020; O'Hara et al., 2020). The systematic placement of Trichodischia also changed along the years; it was first classified in the tribe Macquartiini in Dexiidae (Dexiinae in part) by Townsend (1936), position roughly maintained by Guimarães (1971). However, in O'Hara et al. (2020), this genus was moved to Voriini, alongside most of the Neotropical genera of Macquartiini.

Herein, to clarify this confusion, we redescribe the type species of genus Trichodischia, T. soror, presenting for the first time a full description and illustration of the male terminalia. We also 
synonymized Trichoraea under Trichodischia, confirm T. caerulea comb. rest. and T. soror as valid species, and provide some comments about the taxonomy and host record of the genus.

\section{MATERIAL AND METHODS}

The type material examined of $T$. caerulea (Lectotype) and T. soror (Holotype) is deposited at the Natural History Museum (NHMUK). The additional material used for the redescription of $T$. soror is deposited at the Diptera collection of the Museu de Zoologia da Universidade de São Paulo (MZSP) and at the Museu Nacional, Rio de Janeiro in Brazil (MNRJ). Morphological terminology follows Cumming \& Wood (2017).

For the study of terminalia, the abdomen was dissected from the fourth segment. To digest tissues and clarify structures, the terminalia were placed in a $10 \% \mathrm{KOH}$ solution and heated in boiling water for 10 minutes, neutralized in a $5 \%$ acetic acid solution and rinsed with distilled water. After examination, the dissected parts were placed in glycerin inside plastic microvials and pinned with their respective specimens.

Photographs of the pinned specimens and terminalia were taken using a Leica MC170 HD digital camera attached to a Leica MZ16 stereomicroscope, and the Leica LAS software version 4.12.0. The images were subsequently stacked with the software Helicon Focus 6.7.1, and then edited in Adobe Photoshop CC 2020. The plates were made with Adobe Illustrator CC 2019.

\section{RESULTS}

\section{Taxonomy}

\section{Genus Trichodischia Bigot, 1885}

Trichodischia Bigot, 1885: xlv.

Type species: Trichodischia soror Bigot, 1885, by subsequent designation of Townsend (1916: 9).

References: Townsend (1936: 16, key to Macquartiini genera); Townsend (1939: 68, generic diagnosis); Cortés (1944: 49, taxonomic notes); Cortés (1969: 97, taxonomic notes and revalidation of T. soror) Guimarães (1971: 100, catalogue); Cortés (1974: 35-38, discussion and key to genera of Dexiinae with males with modified hind femora); Guimarães (1977: 76, 89, host record); Henry (1987: 194, list); Evenhuis \& Pont (2004: 60, list of genera described by Bigot); O'Hara \& Henderson (2020: 76, world checklist of genera of Tachinidae); O'Hara et al. (2020: 176, world checklist of tachinids).

\section{Trichoraea Cortés, 1974: 37. Syn. nov.}

Type species: Trichodischia caerulea Bigot, 1885, by original designation.
References: Evenhuis \& Pont (2004: 60, list of genera described by Bigot); O'Hara \& Henderson (2020: 76, world checklist of genera of Tachinidae); O'Hara et al. (2020: 176, world checklist of tachinids).

\section{Diagnosis}

Trichodischia differs from other Neotropical Voriini by the following combination of traits: eye setulose, male with strong orbital setae; parafacial with setulae throughout its whole extension; long prementum, equal to the head height; patch of long and hairs-like setulae on the midventral surface of the hind femur in males; tergites 3 and 4 with a pair of discal setae.

\section{On the taxonomic status of T. caerulea comb. rest. and T. soror}

The confusing taxonomic history of this species, as aforementioned in the introduction, can be clarified herein. Following the generic diagnosis given below, both species share a considerable number of relevant traits that confirm them as belonging to Trichodischia. At the same time, T. caerulea comb. rest. and T. soror present several traits that provide evidence that both species are valid and differ from each other. The key provided by Cortés (1969) and the analysis of type material of both species by the second author provide the conclusive evidence for this claim. Hence, the following diagnostic key to species, a translation and adaptation of Cortés (1969) that contains the evidence discussed, is given:

1 Scutum and abdomen dark metallic blue, with slightly grayish pruinosity; male with proclinate orbital setae on the fronto-orbital plate; wing with vein $R_{4+5}$ setulose at the base and up to the middle of the distance to the r-m; palpus dark brown . T. caerulea Bigot comb. rest.

- Scutum and abdomen brownish black, well covered with grayish pruinosity; male without proclinate orbital setae on fronto-orbital plate; wing with vein $\mathrm{R}_{4+5}$ setulose up to the $\mathrm{r}-\mathrm{m}$; palpus yellow to yellowishbrown... T. soror Bigot

\section{Trichodischia caerulea Bigot, 1885 comb. rest.}

Trichodischia caerulea Bigot, 1885: xlv (description of female). Lectotype female (NHMUK), examined (in good condition).

Type locality: Argentina, Buenos Aires.

References: Brauer (1898: 498, redescription, taxonomic notes); Cortés (1944: 49, T. caerulea as senior synonymous of T. soror); Blanchard (1963: 186 [misidentified, see remarks], host record); Cortés (1969: 97, taxonomic notes; 98, in key); Guimarães (1971: 100, catalogue); Cortés (1974: 35, taxonomic notes; 37, discussion on host records); Guimarães (1977: 76, 106 [misidentified, see remarks], host catalogue); Henry (1987: 194, list); Virla et al. (1999: 10 [misidentified, see remarks], host notes); Molina-Ochoa et al. (2003: 269 [misidentified, see 
remarks], host notes); Evenhuis \& Pont (2004: 60, taxonomic note); O'Hara et al. (2020: 176, world checklist of tachinids).

Trichoraea caerulea (Bigot, 1885).

References: Cortés (1974: 37, new combination and taxonomic notes).
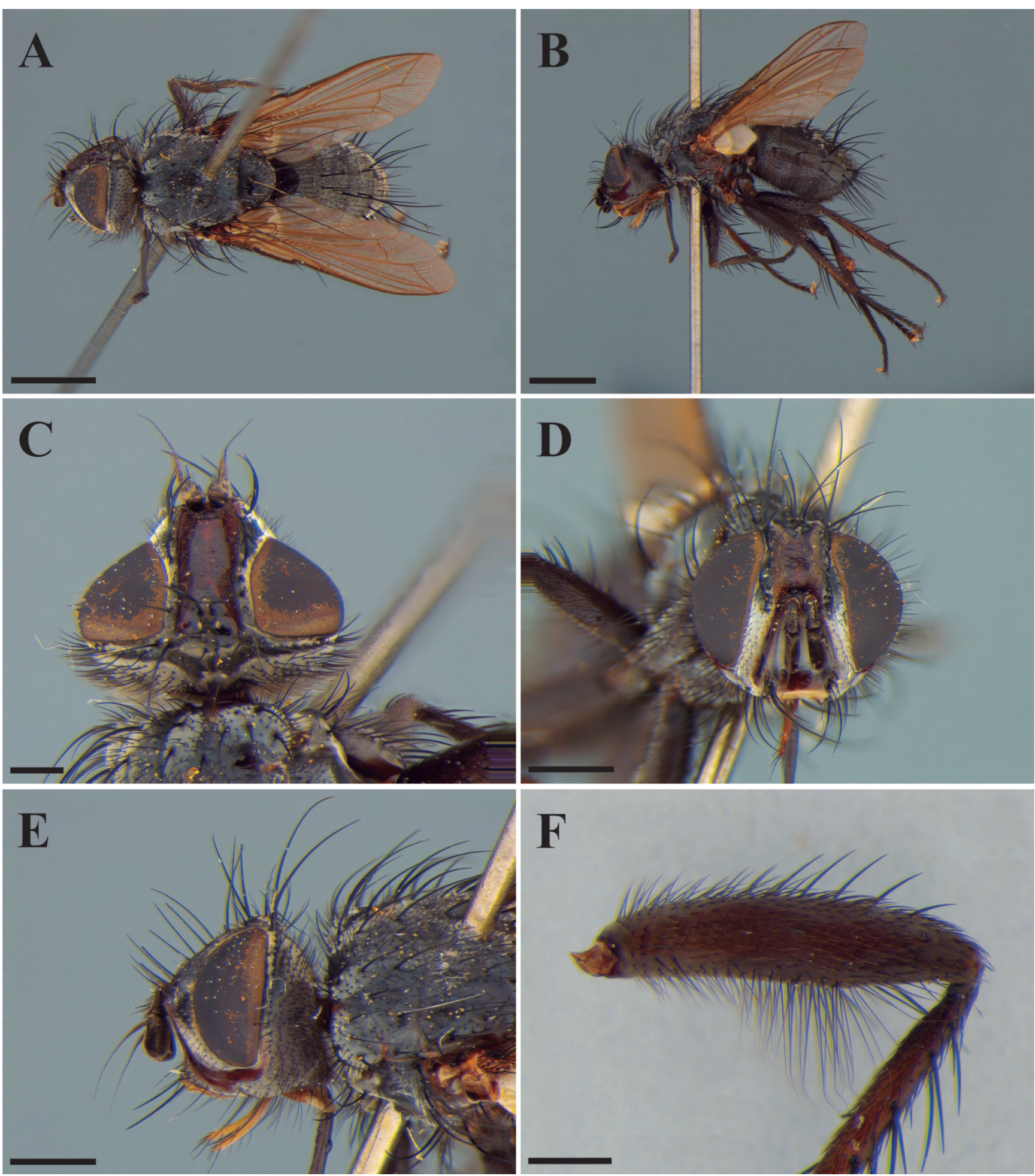

Figure 1. Trichodischia soror (O', Osorno, Chile, MZSP). (A) Dorsal habitus. (B) Lateral habitus. (C) Head, dorsal view. (D) Head, frontal view. (E) Head, lateral view. (F) Hind femur with ventral patch of hairs-like setulae. Scale bars: $A, B=2 \mathrm{~mm}, C, F=0.5 \mathrm{~mm}, D, E=1 \mathrm{~mm}$.

\section{Trichodischia soror Bigot, 1885}

(Figs. 1-3)

Trichodischia soror Bigot, 1885: xlvi (description of male). Holotype male (NHMUK), examined (in good condition).

Type locality: Argentina, Buenos Aires. 
References: Brauer (1898: 499, redescription, taxonomic notes); Cortés (1944: 49, T. soror as junior synonymous of T. caerulea); Parker (1953: 53, cited as T. caerulea, host record; 67, drawing of cephaloskeleton of first instar larva and puparium); Parker et al. (1953: 18, cited as T. caerulea, host record); Blanchard (1963: 186, cited as T. caerulea, host record); Cortés (1969: 97, taxonomic notes and revalidation of $T$. soror); Guimarães

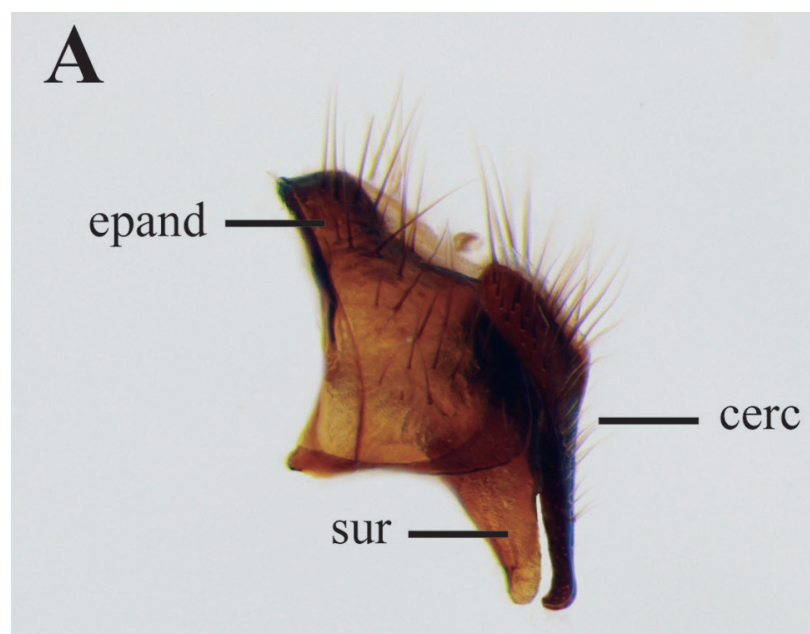

C

phapod

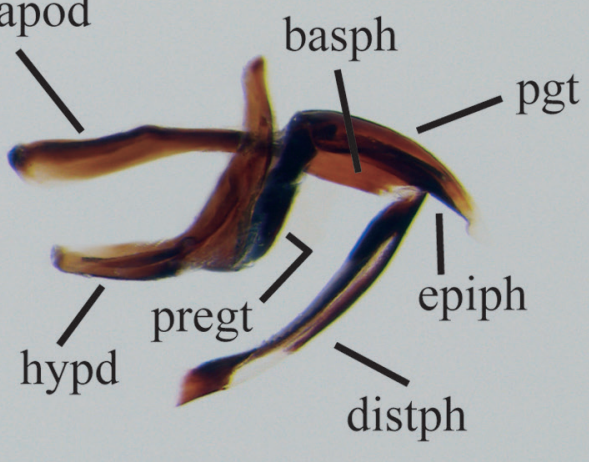

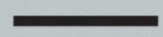

E
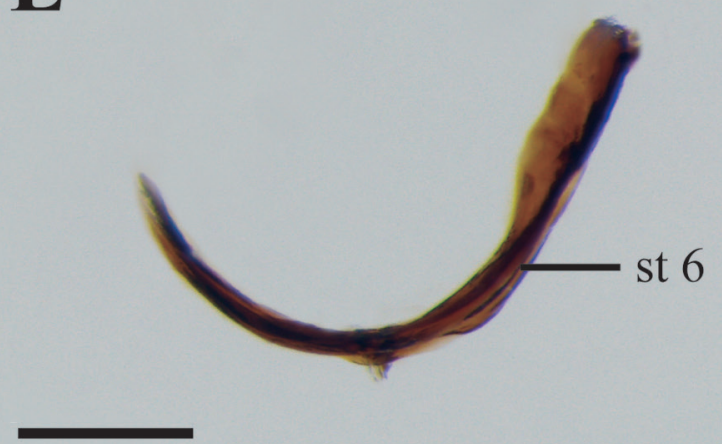

(1971: 100, catalogue); Cortés (1974: 35, taxonomic notes; 37, discussion on host records); Guimarães (1977: 76, 106, cited as T. caerulea, host catalogue); Cortés (1980, 105, distributional records); Tschorsnig (1985: 100, description of male terminalia of Dexiinae); González (1992: 179, populations aspect of tachinids from the National reserve Rio Clarillo - Chile); Virla et al. (1999: 10, host notes); Molina-Ochoa et al.
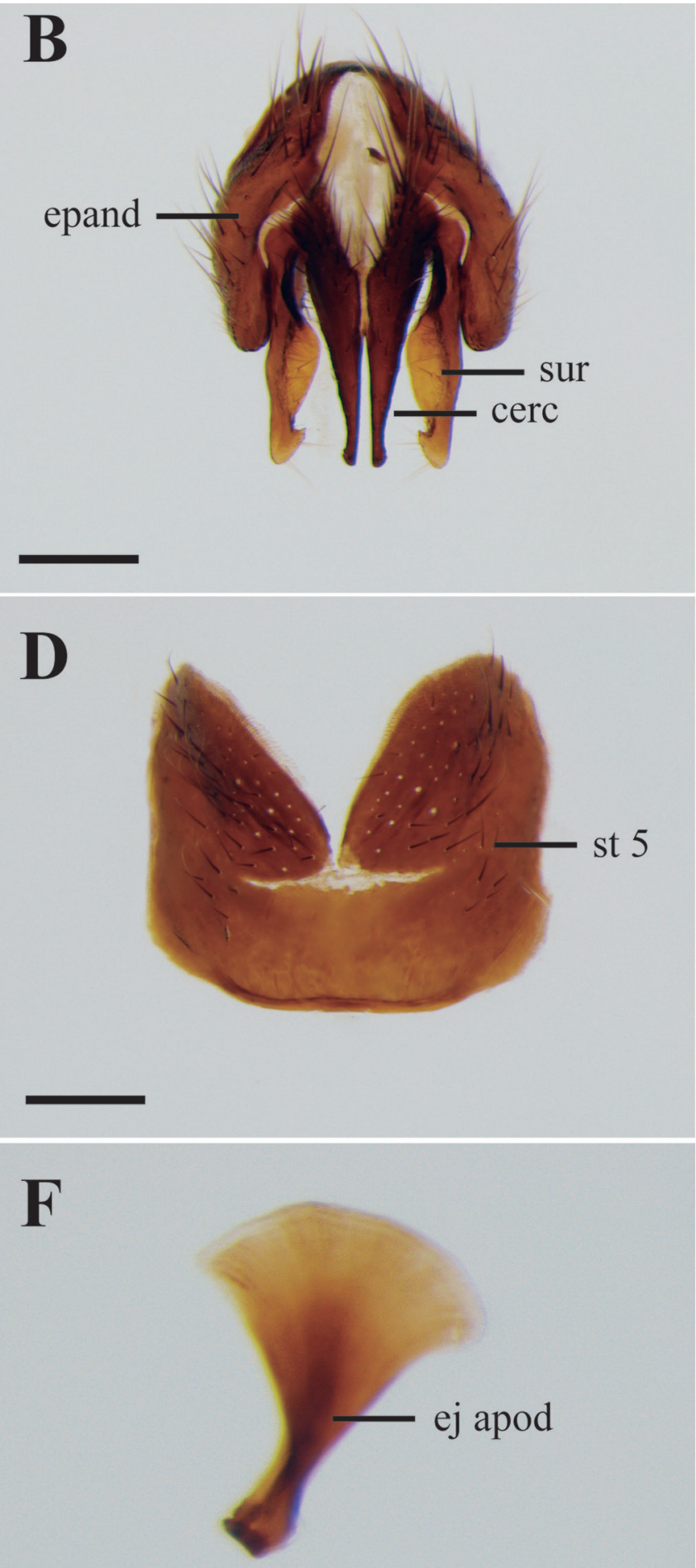

Figure 2. Male terminalia of Trichodischia soror. (A) Epandrium, cerci and surstylus, lateral view. (B) Epandrium, cerci and surstylus, posterior view. (C) Hypandrium, phallapodeme, basiphallus, epiphallus, distiphallus, pregonite, and postgonite lateral view. (D) Sternite 5, ventral view. (E) Sternite 6, posterior view. (F) Ejaculatory apodeme. Scale bars: A-E =0.25 mm, F=0.1 mm. Abbreviations: basph = basiphallus; cerc = cercus; distph = distiphallus; ej apod = ejaculatory apodeme; epiph= epiphallus; epand = epandrium; hypd = hypandrium; pgt = postgonite; phapod = phallapodeme; pregt = pregonite; st = sternite; sur = surstylus. 
(2003: 269, host notes); Evenhuis \& Pont (2004: 60, taxonomic note); O'Hara et al. (2020: 176, world checklist of tachinids).

\section{Additional material examined}

BRAZIL: Santa Catarina: Nova Teutônia, $1 \sigma^{7}$ [dissected], ix.1967, F. Plaumann Leg. (MZSP); Nova Teutônia, 1 ? [dissected], x.1967, F. Plaumann Leg. (MZSP). Chile: Cautín: Villarica, 1 \%, 18.xii.1966, Irwin Leg. (MZSP); Concepción:
Parque Botánico Hualpen, 1 đ [dissected], ii.1970, T. Cekalovic Leg. (MNRJ); Los Lagos: Osorno, 1 ơ, 24.xi.1968, R. Cortés Leg. (MZSP); Malleco: Angol, 1 \&, xi.1972, T. Cekalovic Leg. (MZSP).

\section{Distribution}

Argentina (Buenos Aires), Brazil (Santa Catarina), Chile (Valparaíso, Cautín, Concepción, Los Lagos, and Malleco), Uruguay (Montevideo).

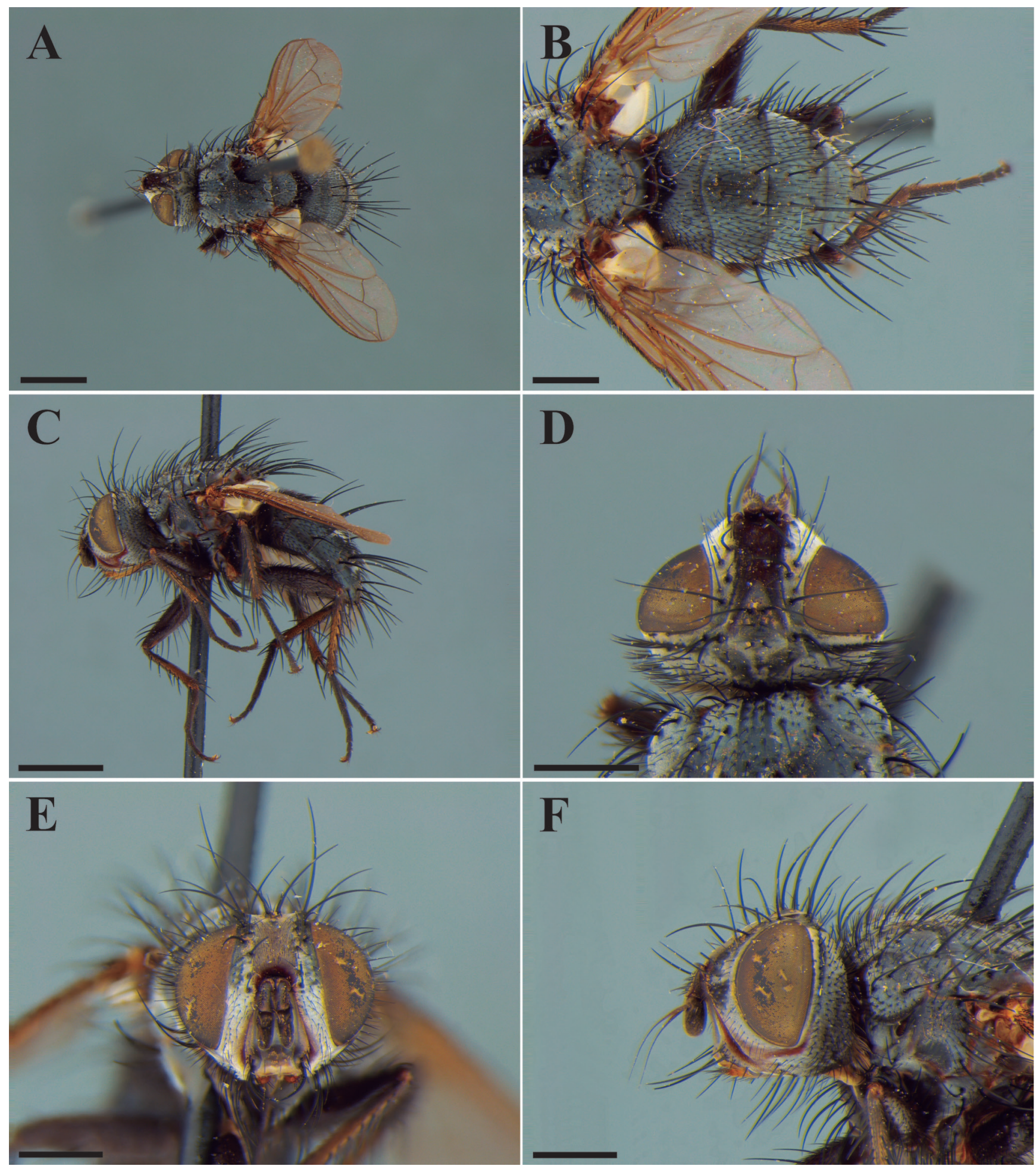

Figure 3. Trichodischia soror ( $\$$, Villarica, Chile, MZSP). (A) Dorsal habitus. (B) Detail of abdomen in dorsal view. (C) Lateral habitus. (D) Head, dorsal view. (E) Head, frontal view. (F) Head, lateral view. Scale bars: $A, C=2 \mathrm{~mm}, B, D=1 \mathrm{~mm}, E, F=1 \mathrm{~mm}$. 


\section{Redescription of male}

Coloration (Fig. 1): Body entirely dark brown to blackish, with gray pruinosity. Palpus yellow to yellowish-brown. Tibiae sometimes slightly yellowish. Wings sub-hyaline, slightly brown, with brown veins; tegula black and basicosta brown. Calypters whitish.

Head (Fig. 1C-E): Dichoptic. Eyes hairy. Fronto-orbital plate setulose. Ocellar tubercle with a pair of strong lateroclinate ocellar setae. Row of 6-8 inclinate frontal setae, arising at level of pedicel. One lateroclinate orbital seta. Inner vertical setae erect. Outer vertical setae lateroclinate. A pair of postocellar setae. One paravertical seta. Postcranium globose, with black hairs. Parafacial setulose along its whole extension. Strong vibrissae surrounded by small setulae. Palpus slender and setulose, about half length of prementum. Lower facial margin straight, not visible in lateral view. Antenna inserted to level of middle of eyes; arista micro-pubescent and with basal third slightly thickened.

Thorax (Fig. 1A-D): Acrostichal setae 1+1, first and second pair absent. Dorsocentral setae $3+3$. Intra-alar setae 1+3. Supra-alar setae 1+3. Postpronotal setae 4, three basal and one anterior. Notopleural setae 2. Postalar setae 2. Proepisternal seta 1, accompanied by 1-2 setulae. Proepimeral seta 1, accompanied by two setulae. Katepisternal setae 3. Anepisternal setae 5-6. Anepimeral seta 1, extending to the posterior margin of upper calypter. Meral setae 4-6. Prosternum bare. Scutellum scattered with setulae, with decussate apical scutellar setae, divergent subapical scutellar and lateral scutellar setae, and straight basal scutellar setae. Wing: A pair of costal spines, one short and other long. Vein $C$ ending just before wing apex. Vein $M_{1}$ ending at wing margin, before the end of vein $C$. Bend of vein M rounded. Cell $r_{4+5}$ open, length of opening shorter than crossvein r-m. Crossvein $\mathrm{dm}$-cu sinuose. Vein $\mathrm{R}_{4+5}$ dorsally setose to crossvein $\mathrm{r}-\mathrm{m}$. Legs: Hind femur with a ventral patch of long and hairslike setulae.

Abdomen (Fig. 1A-B): Globose. Mid dorsal depression of syntergite $1+2$ extending to the middle of segment. Syntergite $1+2$ with concave dorsal margin and one lateral marginal seta. Tergite 3 with one lateral marginal seta, a pair of median marginal setae, and a pair of discal setae. Tergite 4 with a pair of median discal setae, and a row of dorsolateral marginal setae. Tergite 5 with a row of dorsolateral discal setae, and a row of marginal setae. Terminalia (Fig. 2A-F). Sternite 5 with a transversal membranous band, lobes well developed and setulose, and sensilla trichodea absent. Sternite 6 asymmetrical. Tergite 6 undivided, posteriorly setulose, band-shaped gradually tapering sideways, attached to syntergosternite $7+8$ by a narrow membrane. Syntergosternite $7+8$ broad and setulose. Spiracle 6 both on the membrane, and spiracle 7 both on anterior margin of syntergosternite 7+8. Ejaculatory apodeme hand-fan shaped, with narrow basal plate and wide process. Epandrium setu- lose, closed dorsally; posterior epandrial process small and moderately acute; anterior epandrial process triangle-shaped with posterior margin curved; lower lateral margin with developed lobe partially covering the surstylus. Hypandrium with long, up curved and arms not fused; hypandrial apodeme well developed, longer than width, and slightly bowl-shaped. Cerci not fused, tapering distally, with straight inner margins and oblique outer margins in posterior view; beak-shaped distal end in lateral view. Surstylus broad, subtriangular with rounded end in lateral view; medially widened and with hook-shaped distal end in posterior view. Phallapodeme slightly arched, extending a little beyond the hypandrial apodeme; phallic guide short. Basiphallus robust and tube-shaped, projecting into a claw-shaped epiphallus. Distiphallus with ventral sclerite longer than dorsal sclerite; ventral sclerite with distal end dorsally fused; membranous region connecting the distal ends of dorsal sclerite and ventral sclerite. Pregonites subrectangular in lateral view, not fused with each other, basal region slightly expanded and fused with medial plate of hypandrium. Postgonites not fused, narrow and claw-shaped, located dorsolaterally to basiphallus, extending almost until apex of distiphallus.

\section{Female (Figs. 3A-F)}

Similar to male, but with a pair of proclinate orbital setae, and hind femur without the ventral patch of hairslike setulae.

\section{Biology}

Trichodischia soror has been record as a parasitoid of larvae of fall armyworm, Spodoptera frugiperda (Smith) (Lepidoptera: Noctuidae) (Parker, 1953; Parker et al., 1953; Ashley, 1979; Blanchard 1963; Cortés, 1974; Virla et al., 1999; Molina-Ochoa et al., 2003).

\section{Remarks}

As argued earlier, in his host-parasite catalogue, Guimarães (1977) uses the host record derived from Blanchard (1963), that recorded T. caerulai (sic) from Spodoptera frugiperda. This information was followed by some subsequent authors (e.g., Virla et al., 1999; MolinaOchoa et al., 2003). However, these authors overlooked the observations of Cortés (1974) that concluded that the real T. caerulea was misidentified by Blanchard; in reality, he had a T. soror specimen. Hence, all these host records for Trichodischia are from T. soror only. Furthermore, Cortés (1974) believed that the species of Trichodischia treated as new by Parker (1953), and as T. caerulea by Parker et al. (1953), are in reality T. soror.

\section{ACKNOWLEDGMENTS}

We thank the Institute of Biosciences of the University of São Paulo and Silvio Nihei (USP) for the logistical sup- 
port. Deivys Alvarez received funding through a doctoral scholarship from Ministerio de Ciencia, Tecnología e Innovación de Colombia (MINCIENCIAS) and the department of Sucre (Convocatoria № 678 de 2014, Capítulo 2 Doctorado Exterior). Marcelo Santis received funding through a doctoral scholarship from Coordenação de Aperfeiçoamento de Pessoal de Nível Superior (CAPES, process number $88882.333078 / 2019-01$ ). We also thank the reviewers and editor for their comments, although the authors are completely responsible for all the above information.

\section{AUTHORS' CONTRIBUTIONS}

Deivys Alvarez-Garcia: Conceptualization, Investigation, Visualization, Writing - original draft, Writing - review \& editing. Marcelo Santis: Investigation, Visualization, Writing - review \& editing. All the authors actively participated in the discussion of the results, they reviewed and approved the final version of the paper.

\section{REFERENCES}

Ashley, T.R. 1979. Classification and distribution of fall armyworm parasites. The Florida Entomologist, 62(2): 114-123.

Blanchard, E.E. 1963. Dípteros parásitos de Noctuidae argentinos. Revista de Investigaciones Agropecuarias, 17: 129-254.

Brauer, F. 1898. Beiträge zur Kenntniss der Muscaria Schizometopa. Bemerkungen zu den Original exemplaren der von Bigot, Macquart und Robineau-Desvoidy, beschreibenen Muscaria Schizometopa aus der Sammlung des Herrn G.H. Verral. Sitzungsberichte der MathematischNaturwissenschaftlichen Classe der Kaiserlichen Akademie der Wissenschaften. Abteilungen 2, 107: 495-529.

Cortés, R. 1944. Trichodischia Bigot y Dischotrichia n. gen., géneros nuevos de Taquínidos para Chile (Dipt., Tachinidae). Revista Universitária (Universidad Católica de Chile), 29: 49-58.

Cortés, R. 1969. Rehabilitación de una especie bigotiana: Trichodischia caerulea Bigot 1885 diferente de T. soror Bigot 1885 (Diptera, Tachinidae). Revista Universitária (Universidad Católica de Chile), 53(31): 97-99.

Cortés, R. 1974. Sobre cuatro géneros de Dexiinos chilenos (Diptera, Tachinidae) con los fémures posteriores de los machos modificados. Revista Chilena de Entomologia, 8: 35-38.

Cortés, R. 1980. Neotropical Tachinidae (Diptera) I. Notes, records, distribution and descriptions. Revista Brasileira de Entomologia, 24: 105-110.

Cumming, J.M. \& Wood, D.M. 2017. Adult morphology and terminology. In: Kirk-Spriggs, A.H. \& Sinclair, B.J. (Eds.). Manual of Afrotropical Diptera. Suricata 4. Pretoria, South African National Biodiversity Institute Graphics \& Editing. v. 1, p. 89-133.
Evenhuis, N.L. \& Pont, A.C. 2004. The Diptera genera of Jacques-MarieFrangile Bigot. Zootaxa, 751: 1-94.

González, C.R. 1992. Tachinids flies from the National reserve Rio Clarillo (Diptera: Tachinidae). Acta Entomologica Chilena, 17: 175-185.

Guimarães, J.H. 1971. Family Tachinidae (Larvaevoridae). In: Papavero, N. (Ed.). A Catalogue of the Diptera of the Americas South of the United States. Vol. 104. São Paulo, Museu de Zoologia, Universidade de São Paulo. p. 1-333.

Guimarães, J.H. 1977. Host-parasite and parasite-host catalogue of South American Tachinidae (Diptera). Arquivos de Zoologia, 28: 1-131.

Henry, A. 1987. Los taquínidos (Diptera: Tachinidae) de la colección del Instituto de Entomologia de la Universidad Metropolitana de Ciencias de la Educación. Acta Entomológica Chilena, 14: 189-207.

Molina-0choa, J.; Carpenter, J.E.; Heinrichs, E.A. \& Foster, J.E. 2003. Parasitoids and parasites of Spodoptera frugiperda (Lepidoptera: Noctuidae) in the Americas and Caribbean Basin: An inventory. Florida Entomologist, 86(3): 254-289.

0'Hara, J.E. \& Henderson, S.J. 2020. World genera of the Tachinidae (Diptera) and their regional occurrence. Version 11. PDF document, 90pp. Available: http://www.nadsdiptera.org/Tach/WorldTachs/Genera/Gentach ver11. pdf. Access: 26/01/2021.

O'Hara, J.E.; Henderson, S.J. \& Wood, D.M. 2020. Preliminary checklist of the Tachinidae (Diptera) of the world. Version 2.1. PDF document, 1039p. Available: http://www.nadsdiptera.org/Tach/WorldTachs/Checklist/ Tachchlist ver2.1.pdf. Access: 26/01/2021.

Parker, H.L. 1953. Miscellaneous notes on South American dipterous parasites. Bollettino del Laboratorio di Entomologia Agraria Filippo Silvestri, 12: 45-73.

Parker, H.L.; Berry, P.A. \& Guido, A.S. 1953. Host-parasite and parasite-host lists of insects reared in the South American Parasite Laboratory during the period 1940-1946. Revista de la Asociación de Ingenieros Agronómos, 23(92): 15-112.

Townsend, C.H.T. 1916 Designations of muscoid genotypes, with new genera and species. Insecutor Inscitiae Menstruus, 4: 4-12.

Townsend, C.H.T. 1936. Manual of myiology in twelve parts. Part IV. Oestroid classification and habits. Dexiidae to Exoristidae. São Paulo, Itaquaquecetuba. 303p.

Townsend, C.H.T. 1939. Manual of myiology in twelve parts. Part IX. Oestroid generic diagnoses and data. Thelairini to Clythoini. São Paulo, Itaquaquecetuba. 270p.

Tschorsnig, H.P. 1985. Taxonomie forstlich wichtiger Parasiten: Untersuchungen zur Struktur des männlichen Postabdomens der Raupenfliegen (Diptera, Tachinidae). Stuttgarter Beiträge zur Naturkunde, Serie A (Biologie), 383: 1-137.

Virla, E.G.; Colomo, M.V.; Berta, C. \& Valverde, L. 1999. Complejo de los parasitoides del "gusano cogollero" del maíz, Spodoptera frugiperda, em la República Argentina (Insecta: Lepidoptera). Neotropica, 45(113/114): 3-12. 